\title{
Smart device development for cold chain control in biological materials
}

\section{Desarrollo de sistema inteligente para el control de la cadena de frío de materiales biológicos}

\author{
RAMÍREZ, Mayra†*, LÓPEZ, Pedro, GONZÁLEZ, Juana and MENDOZA, Tania \\ Universidad Politécnica del Bicentenario, Mexico. \\ ID $1^{\text {st }}$ Author: Mayra, Ramírez \\ ID $1^{\text {st }}$ Coauthor: Pedro, López \\ ID $2^{\text {nd }}$ Coauthor: Juana, González \\ ID $3^{\text {rd }}$ Coauthor: Tania, Mendoza
}

DOI: $10.35429 / J R D .2020 .18 .6 .18 .21$

Received: July 30, 2020; Accepted: December 19, 2020

\begin{abstract}
In Mexico, controlling and monitoring the cold chain in vaccines is one of the biggest problems nowadays. Vaccines are biological products sensitive to variations in light, humidity, time, and mainly temperature. When some of those parameters get lost because of an external situation, consequently, these vaccines lose their functionality, that is why is important a portable device adapted to the design is developed according to the software-hardware prototype, because of this, different variations in those vaccines can be monitored, temperature and humidity for example. According to this, is possible to transfer biological samples and medicines, without forgetting of course to apply the rules in handling the control of the cold chain, guaranteeing the safety of those products. The purpose of this is prevent that the cold chain in medicines and biological samples within health institutions get lost. This make possible to achieve a better control and monitoring applying a versatile system, which is based according to the norms and safety standards.
\end{abstract}

\begin{abstract}
Resumen
En México, controlar y monitorear la cadena de frío en vacunas es uno de los mayores problemas hoy en día. Las vacunas son productos biológicos sensibles a las variaciones de luz, humedad, tiempo y principalmente temperatura. Cuando algunos de esos parámetros se pierden debido a una situación externa, en consecuencia, estas vacunas pierden su funcionalidad, por eso es importante que se desarrolle un dispositivo portátil adaptado al diseño de acuerdo con el prototipo de software-hardware, debido a esto, diferentes variaciones en esas vacunas pueden controlarse, por ejemplo, la temperatura y la humedad. De acuerdo con esto, es posible transferir muestras biológicas y medicamentos, sin olvidar, por supuesto, aplicar las reglas en el manejo del control de la cadena de frío, garantizando la seguridad de esos productos. El objetivo es evitar que se pierda la cadena de frío en medicamentos y muestras biológicas dentro de las instituciones de salud. Esto permite lograr un mejor control y monitoreo aplicando un sistema versátil, que se basa en las normas y estándares de seguridad.
\end{abstract}

Muestras biologicas, Cadena de frío, Temperatura

Biological samples, Cold chain, Temperature

a and MENDOZA, Tania. Smart device development for Citation: RAMÍREZ, Mayra, LÓPEZ, Pedro, GONZÁLEZ, Juana and MENDOZA, Tania. Smart
cold chain control in biological materials. Journal of Research and Development. 2020. 6-18:18-21.

\footnotetext{
* Correspondence to the Author (Email: mramirezq@upbicentenario.edu.mx)

$\uparrow$ Researcher contributing as first author.
} 


\section{Introduction}

The cold chain systems for biological materials, vaccines and medicines is a topic of great importance since it directly impacts the user's health, the correct storage, transport and distribution of these substances prolongs their useful life, on this way guarantees efficiency of its operation [1] and [2]. However, we know that limited resources and lack of adequate technology for the cold chain in the transfer of these substances is an area of opportunity [3]; that would bring great benefits to the health sector in our country [4] and [5].

A bad process in the cold chain could have serious consequences, for example in 2015 an adverse accident occurred in Chiapas, due to the failure in the process of the cold chain of vaccines reported by the IMSS, this cause 31 minors, 29 required hospitalization and two died, therefore it is important to note that a cold chain guarantees to the costumers that the product they get has been kept within a temperature range during transport, storage, sale or distribution.

According to the data obtained in an investigation in the health units in Silao town in Guanajuato city, the vaccination transport protocols in vaccination campaigns are not very automated, it consists of an ice maker that has a refrigerant attached at the top and in the inside of it a hole to insert a mercury thermometer.

The process to verify that the cold chain is maintained in vaccination campaigns is to open the cooler every 2 hours to record the temperature, since it does not have a system that allows them to verify the temperature of the container without the need to open the lid, which causes loss of the cold chain.

That is why it is necessary to develop an intelligent temperature and humidity monitoring system for the refrigeration equipment that stores and transports such substances; which is considered to be an integrated system that allows to record a graphic history of the cold and humidity chain, with the objective of efficiently controlling the parameters set by OMS and the adjustment of Mexican regulations for each substance.
The system is considered as an intelligent red neuronal that selects the established parameters for blood, organs, vaccines and medications.

It will also have a system that alerts audibly and visually in case of the parameters detected by the sensors were not correct, and location that can be tracked by GPS, will also improve the quality in the cold chain process and bring great benefits that could help to improve the attention to the needs of each costumer.

It is expected that the implementation of this system in Health Facilities in Silao Guanajuato solves the current cold chain issue, improving their processes and providing a safe service that will benefit the users directly.

\section{Methodology}

An investigation was carried out to condition the sensors to be used, subsequently the different types of analogic and digital sensors was used to quantify the measurement of temperature. Next, we programmed the Data Acquisition Card, and designed an algorithm that al lowed us to analyze and put the collected data in a chart. This information was then processed so as to elaborate a database and a platform. We also incorporated an auditive and visual alarm system. Finally, we used analyzers to verify the measurements obtained.

\section{Results}

A comparison of the different analog and digital sensors response-time, in order for us to be able to choose the most appropriate one. Table 1 and graphic 1 show the difference in the response of the 4 sensors detected in the test (cold water, ambient temperature and body temperature), as well as the mercury thermometer and Omron taken as control due to their standards are established. 


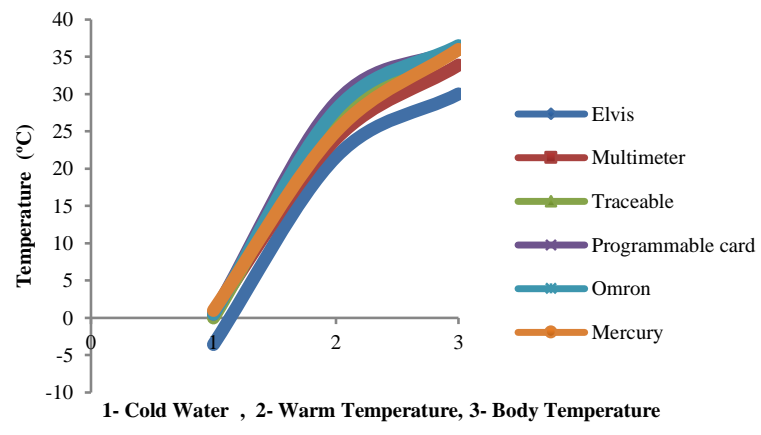

Graphic 1 Characterization graph of temperature sensors

Source: own work [Excel 2013]

\begin{tabular}{|c|c|c|c|}
\hline & $\begin{array}{c}\text { Cold } \\
\text { Water } \\
{ }^{\circ} \mathrm{C}\end{array}$ & $\begin{array}{c}\text { Warm } \\
\text { Temperature }{ }^{\circ} \mathrm{C}\end{array}$ & $\begin{array}{c}\text { Body } \\
\text { Temperature } \\
{ }^{\circ} \mathrm{C}\end{array}$ \\
\hline Elvis & -3.567 & 21.57 & 30.03 \\
\hline Multimeter & 0.7 & 24 & 33.9 \\
\hline Traceable & 0 & 27 & 36 \\
\hline $\begin{array}{l}\text { Programmable } \\
\text { card }\end{array}$ & 0.5 & 28.87 & 36.06 \\
\hline Omron & 0.5 & 27.9 & 36.5 \\
\hline Mercury & 1 & 25 & 36 \\
\hline
\end{tabular}

Table 1 Characterization of temperature sensors Source: own work [Excel 2013]

Using the given sensor, a code in Arduino was created so as to get the temperature data of 5 DS18B20 sensors, which were strategically located within the cold chain device.

The chosen sensor for the development of the device, due to its response time, was a digital sensor, which happens to be humidity resistant, and it shows an optimal temperature range for the task.

The data obtained by the temperature sensor is shown in the serial monitor of the Arduino, it is also to be linked to a MySql server via internet connection and then is saved in a text file, recording date and time.

The database that was developed requires Log ID, user and password to $\log$ in. (Figure 1), sticking to the security and dataencryption protocols.

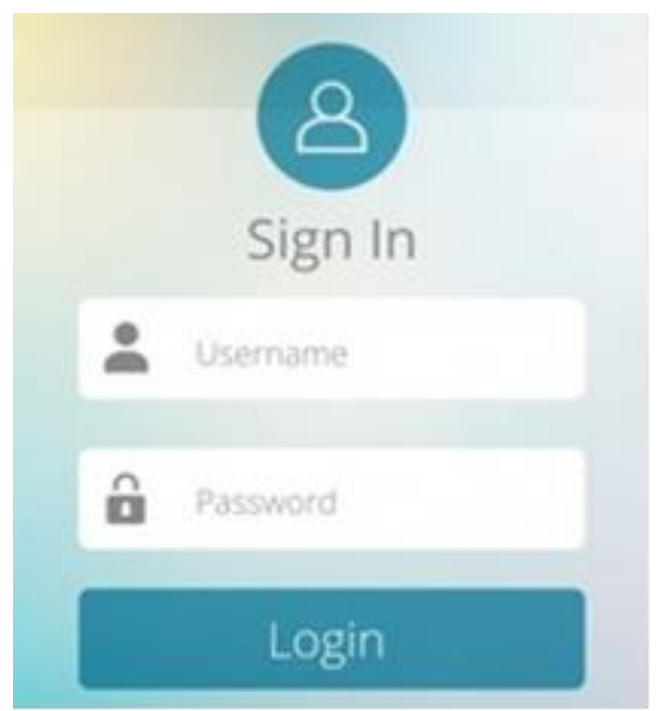

Figure 1 Login into the database Source: own work [PHP]

Data monitoring is done through a sensor network, located strategically (sample, room and device temperature) in order to control the biological samples cold chain. These sensors are monitored in real time, locally, through the design of a graphic interface (Figure 2).

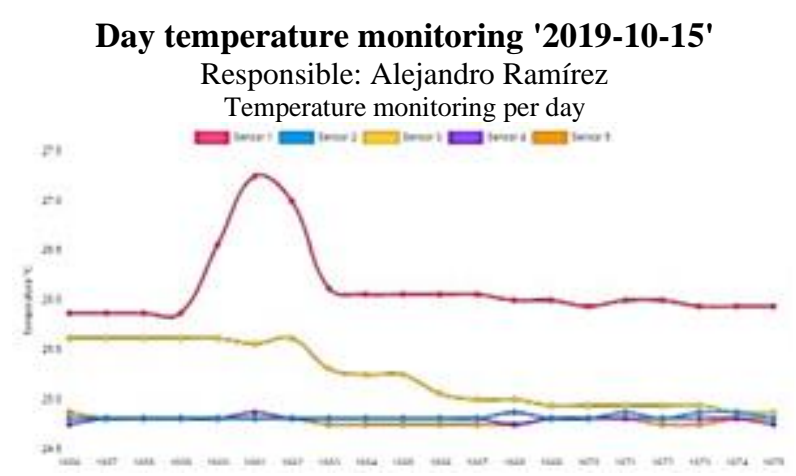

Figure 2 Graphs of the database Source: own work [PHP]

An appendix regarding "Dynamic search" is considered, to analyze the Daily Temperature Logs, showing them on a PDF file (Figure 3).

\begin{tabular}{|c|c|c|c|c|c|c|}
\hline 10 & DATA & SENSOR 1 "4C & SENSOR 2 "C & sensos 3 œC & SENSOR $4^{\circ} \mathrm{C}$ & sensor 5 NC \\
\hline 1656 & $\begin{array}{l}15 / 100 / 19 \\
133611\end{array}$ & 25.87 & 24.81 & 8.62 & 24.75 & 24.87 \\
\hline 2657 & $\begin{array}{l}15 / 10 / 19 \\
133622\end{array}$ & 25.87 & 24.81 & 8.62 & 24.81 & 24.81 \\
\hline 1658 & $\begin{array}{l}15 / 01 / 19 \\
133633\end{array}$ & 2587 & 24.81 & 25.62 & 24.81 & 2481 \\
\hline
\end{tabular}

Figure 3 PDF format of report

Source: own work [PHP]

Finally, the platform was moved to a Raspbian system to have a more ergonomic design and installed on a computer board (SBC) (Figure 4). 


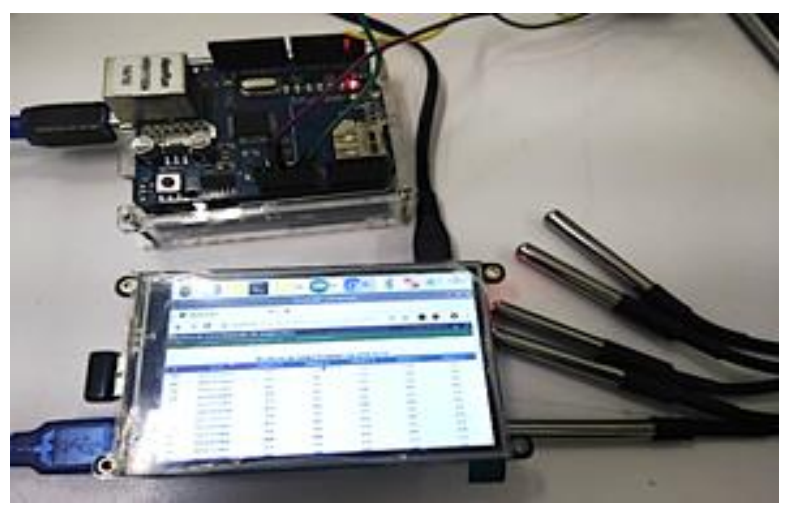

Figure 4 Visualization of the database in the Raspbian System

Source: own work [PHP]

A prototype was made (Figure 5), for the implementation of the control system for the acquisition of physical measurement parameters for the biological samples contained in the device.

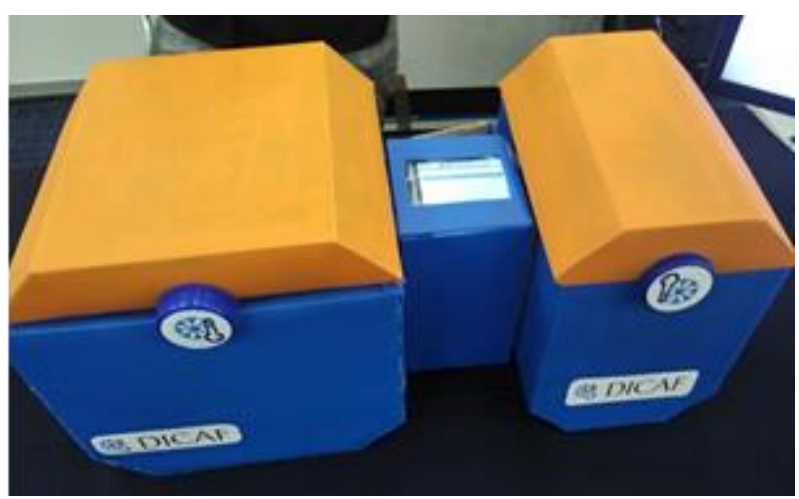

Figure 5 Visualization of the database in the Raspbian System

Source: Own work [Ramírez, 2020]

\section{Annexes}

We are grateful with "SICES" because of the economic support in the young researchers program which it was necessary to develop the prototype, also we must say thank you to the Universidad Politécnica del Bicentenario educational program and because we could use the university infrastructure.

\section{Conclusions}

In Mexico there is a lack in applications to technologies focused on the transport of vaccines, so an intelligent system was developed that allows monitoring measurement parameters for the conservation of the cold chain.
The implementation of this system in hospital institutions will optimize times, processes, resources and above all it will guarantee safety and conservation in the transfer of biological samples by applying the regulations in force in our country.

\section{References}

I. Flores, G. A. (1999). Las vacunas y la cadena de frio. Honduras Pediatrica, XX, 3.

II. II. Ng, C.Z, Lean, Y.L., Yeoh, S.F., Lean, O.Y., Lee, K.S. (2020). Cold chain timeand temperature-controlled transport of vaccines: a simulated experimental study. Clinical and Experimental. Vaccine Research 9 (1), 8-14

III. Ortega, P. (2007). Mantenimiento de la cadena del frío para las vacunas: una revisión sistemátcia. Gac. Sanit; 21(4):343-348

IV. Ortega, P., Astasio, P., Albaladejo, R., Gomez M., (2002), Esp Salud Pública; 76: 333-346

V. Tuells J. (2009). El frágil inicio de la cadena de frío en España, Gac. Sanit; 24(4): 354-357. 